\title{
III Międzynarodowa Konferencja Naukowa „Profilaktyka, wsparcie i resocjalizacja a środowisko lokalne. Perspektywy krytyczne" i VII Międzynarodowy Probacyjny Turniej Piłkarski, Lębork 05-06 lipca 2013 r.
}

Tegoroczne lęborskie spotkania, jeszcze przed konferencyjnym startem nabrały szczególnego charakteru. Co zatem wpłynęło na tę zmianę, odstąpienia od swego rodzaju rutyny, nie rozumianej jednak w tym wypadku pejoratywnie? Po pierwsze: otwarcie się $\mathrm{w}$ ramach spotkania konferencyjnego na nowe środowiska uniwersyteckie oraz instytucje zajmujące się pomocą i wsparciem. Tym razem organizatorzy zaprosili pracowników dydaktycznych z kilku uniwersytetów: poznańskiego, szczecińskiego, toruńskiego, Politechniki Koszalińskiej i WWSSE w Środzie Wielkopolskiej. Dodatkowo w konferencji i turnieju uczestniczyli studenci i doktoranci uniwersytetów: poznańskiego i toruńskiego, którzy objęli swoją opieką dzieci z zagrożonych wykluczeniem społecznym rejonów miasta. Po drugie: założenie krytycznej perspektywy spojrzenia na konferencyjną tematykę, co w efekcie stanowiło o oryginalności i wyjątkowej aktualności niektórych wystąpień. Dzięki temu recepcja konferencyjnych referatów, była w ocenie organizatorów zdecydowanie lepsza niż dotychczas. Po trzecie: co dla całego przedsięwzięcia jest bardzo ważne, gościem spotkania był Prezes Sądu Okręgowego w Słupsku, który uczestniczył aktywnie w tegorocznej konferencji. Po czwarte: wśród konferencyjnych prelegentów znaleźli się przedstawiciele organizacji pomocowych. Po piąte: w ramach konferencyjnego spotkania odbyła się premiera książki, jej roboczej jeszcze wersji, w której znaczna część tekstów była autorstwa osób związanych z Wielkopolskim Stowarzyszeniem Kura- 
torów Sądowych. Idea determinująca działania organizatorów lęborskiego przedsięwzięcia, znalazła odzwierciedlenie w formule publikacji, będącej efektem współpracy środowisk naukowych, władz lokalnych i organizacji pozarządowych.

Tegoroczna konferencja odbyła się w Sali Rajców w Starostwie Powiatowym w Lęborku, dlatego też obrady otwierał Starosta Powiatu Lęborskiego Witold Tyburski, który nawiązywał do specyfiki tego miejsca i w tym kontekście sytuował konferencyjne spotkanie. Przewodniczący Rady Miasta Lęborka Adam Stenka wskazywał natomiast na ciągłość i konsekwencję organizatorów lęborskich wydarzeń, zwracając uwagę na ogólnopolski i międzynarodowy charakter spotkania. Wojciech Mroczkowski, Prezes WSKS, zaakcentował aktualność tematyki konferencyjnej, uwzględniając perspektywę przekształceń rodzimej probacji.

Merytoryczną część lęborskiego spotkania zainaugurował doc. dr Przemysław Frąckowiak rektor WWSSE w Środzie Wielkopolskiej. Jego referat udanie wprowadził słuchaczy w rozważania dotyczące krytycznych spostrzeżeń w wymiarze resocjalizacyjnych funkcji kapitału społecznego.

Jednocześnie kontynuacją rozważań kolegi doc. dr Frąckowiaka było odwołujące się do pryncypiów oddziaływań pomocowo-resocjalizacyjnych, przesłanie autorstwa nieobecnego Księdza Profesora dr hab. Czesława Kustry z WNP UMK w Toruniu, który w autorskim, niepublikowanym wcześniej tekście, podzielił się z uczestnikami konferencji swoimi przemyśleniami na temat źródeł, ważnych dla resocjalizacyjnych oddziaływań, sytuując je bezpośrednio w judeochrześcijańskiej perspektywie naszych cywilizacyjnych i kulturowych korzeni (pełny tekst Ks. Profesora Kustry dostępny jest na stronie internetowej WSKS).

Kolejnym prelegentem był kolega Robert Cotterell, dyrektor okręgu probacyjnego w Barnsley w Wielkiej Brytanii, który w tym roku przedstawił bardzo interesującą analizę sytuacji probacji w Zjednoczonym Królestwie. Uwzględniając kontekst koncepcji prywatyzacji części dotychczas wykonywanych przez kuratorów zadań, krytycznie odniósł się do koncepcji zmian wprowadzanych w brytyjskim systemie. Wystąpienie brytyjskiego gościa zainicjowało ciekawą dyskusję, w którą zaangażowali się uczestnicy spotkania.

Wystąpienie dr Pawła Popka z Uniwersytetu Szczecińskiego, koncentrowało się na przedstawieniu koncepcji wsparcia oddziaływań probacyjnych, poprzez działania stymulujące aktywność i odpowiedzialność, wzbogacone o wskazanie konkretnych form pracy przydatnych praktykom resocjalizacji.

Każda konferencja posiada swoich bohaterów, liderów lub lidera, którego wystąpienie ogniskuje zainteresowanie, determinuje często pokonferen- 
cyjne refleksje. Jednym z bohaterów lęborskiego spotkania był doktorant Filozofii UMK w Toruniu, kolega Tomasz Siwiec. Jego pasja i zaangażowanie w wystąpienie, w którym wykorzystując dostępny sobie zakres wiedzy z zakresu etyki, dokonał błyskotliwej analizy Kodeksu Etyki Kuratora Sądowego, spotkała się ze szczególnym zainteresowaniem uczestników konferencji. Wskazania wynikające $\mathrm{z}$ analizy kolegi doktoranta, winny skłonić środowisko kuratorskie do rozważenia poważnych zmian w tym jakże ważnym dokumencie. Szczegółowa analiza KEKS-u (to skrót używany przez autora) znajdą czytelnicy w promowanej na konferencji publikacji.

Pierwszą część konferencji zamknęło wystąpienie nt. Obrazu kuratora sądowego w popkulturze, autorstwa studentów IV roku WNP UMK w Toruniu: Alicji Kamyszek, Klaudii Chojnackiej, Katarzyny Chojnackiej, Celiny Janus i Dawida Dębowskiego. Prezentacja została wyłoniona spośród 14 uczestniczących w konkursie w ramach zajęć z Europejskich systemów resocjalizacji na UMK w Toruniu. Prezentacja oraz sonda uliczna przygotowana przez studentki: Angelikę Kulewską i Ewę Szymczak, pokazuje pewien wybiórczy, ale jednak interesujący, współczesny obraz kuratora sądowego (prezentacja i sonda są dostępne na stronie internetowej WSKS).

Po przerwie prelekcje zainaugurował kolega Roman Zielonka z Niemiec. Kolejny raz spostrzeżenia kolegi Romana, wynikające z jego pracy w firmie GSM Training and Integration GMBH, wprowadzającej i realizującej projekty socjalnego wsparcia na terenie Europy, uświadomiły uczestnikom spotkania, szerokie możliwości działań, jakie daje kuratorom niemieckim, współpraca z tego rodzaju podmiotami.

Kolejne wystąpienie autorstwa Ks. dr Mariusza Kołacińskiego, dotyczyło pomocy i wsparcia osób starszych. Prelegent jest etykiem, pracownikiem dydaktycznym Politechniki Koszalińskiej oraz Uniwersytetu Szczecińskiego, wykładającym gościnnie na wielu europejskich uniwersytetach. Ks. dr Mariusz Kołaciński wskazał na interdyscyplinarność koncepcji realizowanego w Koszalinie modelu opieki nad osobami starszymi. Interesujące dla słuchaczy były argumenty, których używał występujący, dla opisu referowanego konceptu opieki: autonomia, rozwój i wolność osoby starszej. Atrakcyjność wystąpienia wzbogaciły żarty językowe oraz wypowiedzi pracujących nad koszalińskim projektem sióstr zakonnych z Włoch i Filipin.

Reprezentująca Fundację Pomocy Wzajemnej Barka, Dagmara Szlandrowicz, przedstawiła funkcjonowanie fundacji, ze szczególnym uwzględnieniem tworzenia partnerstw lokalnych, a w konsekwencji wykorzystywania ekonomii społecznej do integracji osób znajdujących się w trudnej sytuacji życiowej. 
Ostatnimi występującymi, byli koledzy kuratorzy Marek Fons i Andrzej Stępniak, reprezentujący Krajowe Stowarzyszenie Resocjalizacji. Kuratorzy zawodowi przestawili uczestnikom konferencji realizowane projekty profilaktyczne i resocjalizacyjne. Ciekawym konceptem był wprowadzany z powodzeniem, program odwiedzania przez uczniów zakładów karnych $\mathrm{w}$ formule wizyt studyjnych. Wystąpienie prelegentów zainicjowało ciekawą dyskusję, w której pytano kuratorów z Poznania m.in. o ich kolejne projektowe plany.

Podsumowania obrad dokonali doc. dr Przemysław Frąckowiak i dr Michał Szykut, dziękując wszystkim uczestnikom konferencji za cierpliwość, a prelegentom za interesujące wystąpienia.

Wskazane we wstępie sprawozdania nowe elementy charakteryzujące tegoroczne lęborskie wydarzenia udowadniają, że udaje nam się z powodzeniem realizować swego rodzaju triadę aktywności: konferencja o coraz wyższym poziomie merytorycznym (w tym także działalność wydawnicza), rozgrywki piłkarskie o coraz większym prestiżu ${ }^{1}$ oraz działania na rzecz potrzebujących pomocy, w tym roku dla dzieci z lęborskich placówek opiekuńczych (co prawdopodobnie stanie się już tradycją). Najważniejsze jednak, moim zdaniem jest to, że coroczne lęborskie spotkania owocują powstaniem swego rodzaju społeczności: kuratorów z wielu miejsc kraju i za granicy, pracowników dydaktycznych uczelni wyższych, studentów, pracowników instytucji i organizacji pomocowych, którzy w tym letnim, zdawać by się mogło niesprzyjającym terminie, przyjeżdżają do Lęborka i aktywnie uczestniczą w corocznych spotkaniach.

Michał Szykut

1 Wraz z Konferencją odbywa się od siedmiu lat w Lęborku Międzynarodowy Probacyjny Turniej Piłkarski, w którym uczestniczą przedstawiciele służb kuratorskich z kraju i zagranicy, a także drużyny reprezentujące środowiska wymiaru sprawiedliwości i organizacje pomocowe. Taka formuła aktywności służy nie tylko integracji konferencyjnej społeczności, ale stwarza warunki do promowania idei probacji w społeczeństwie. 